\title{
Potential application of chitosan-based nanoparticles containing essential oils against mosquitoes, moths and beetles
}

\author{
Ana Maria da Silva Maia ${ }^{a^{*}(\mathbb{O}}$ \\ a Universidade Federal do Tocantins, Brasil \\ *Autor correspondente (anamaia@uft.edu.br)
}

\section{N F O}

Keyworks
pest control
polymer nanoparticl
biological assay
in vivo test
larvicidal activity
fumigant toxicity

\begin{abstract}
A B S T R A C T
The association between the use of synthetic insecticides and the appearance of resistant insects, human poisoning and the environment contamination generated the need to develop new forms to pest control, and essential oils stand out as an alternative. However, due to their volatility and instability, their use in native form is unfeasible. It is possible to circumvent these problems by their encapsulation, and the use of polymeric nanoparticles for this purpose has many advantages, since these systems prevent the oil degradation, and control its release. The first in vivo trials of chitosan nanoparticles containing essential oils with insecticidal activity were published in the late 2010s. Considering the growing interest in this subject, as can be seen from the increase in the number of publications, this review aimed to gather all the papers that presented biological assays using essential oils encapsulated in chitosan nanoparticles against insects. Further, the techniques used to prepare these nanoparticles are also discussed. It was possible to note that the technique called complex coacervation led to smaller particles and most articles describing in vivo tests of chitosan nanoparticles containing essential oils assess their larvicidal activity. Among the tested nanoparticles, the one that had the best larvicidal activity in acute toxicity tests were those obtained by complexing of chitosan with cashew gum and those with the best residual activity were the crosslinked with glutaraldehyde. Chitosan nanoparticles containing essential oils also increased their insecticidal activity in toxicity tests against adult beetles.
\end{abstract}

\section{R E S U M O}

Potencial aplicação de nanopartículas a base de quitosana contendo óleos essenciais contra mosquitos, mariposas e besouros

A associação entre o uso de inseticidas sintéticos e o surgimento de insetos resistentes, intoxicações humanas e contaminação do meio ambiente gerou a necessidade do desenvolvimento de novas formas de controle de pragas, e os óleos essenciais se destacam como alternativa. Porém, devido à sua volatilidade e instabilidade, seu uso na forma nativa é inviável. É possível contornar esses problemas por meio do seu encapsulamento, e o uso de nanopartículas poliméricas para esse fim apresenta vantagens, pois esses sistemas evitam a degradação do óleo e controlam sua liberação. Os primeiros ensaios in vivo de nanopartículas de quitosana contendo óleos essenciais com atividade inseticida foram publicados no final da década de 2010. Considerando o interesse crescente neste assunto, como pode-se observar pelo aumento no número de publicações, esta revisão teve como objetivo reunir todos os trabalhos que apresentaram ensaios biológicos utilizando óleos essenciais encapsulados em nanopartículas de quitosana contra insetos. Além disso, as técnicas usadas para preparar essas nanopartículas também são discutidas. Foi possível notar que a técnica denominada coacervação complexa gerou partículas menores e a maioria dos artigos que descreve testes in vivo de nanopartículas de quitosana contendo óleos essenciais avaliam sua atividade larvicida. Dentre as nanopartículas testadas, as que apresentaram melhor atividade larvicida em testes de toxicidade aguda foram as obtidas por complexação da quitosana com goma do cajueiro e as com melhor atividade residual foram as reticulados com glutaraldeído. Nanopartículas de quitosana contendo óleos essenciais também aumentaram a atividade inseticida destes em testes de toxicidade contra besouros adultos. 


\section{INTRODUCTION}

Insects are a class of highly specialized animals (Engel, 2015) and most of them are beneficial to mankind, whether by participating in pollination of plants, providing products of commercial interest, such as silk and honey or simply by their participation in the environmental balance (You et al., 2005; Rader et al., 2016). However, the alteration of their natural habitats and other human actions can lead to greater contact between them and humanity, which can result in damage to agriculture (Bradshaw et al., 2016); breeding animals, because insects can act as vectors of diseases and their feeding can cause animal annoyance and distress (Kamut e Jezierski, 2014; Bartlow et al., 2019; Barlaam et al., 2020); and ecosystems, for example, by the introduction of invasive insect species that damage forests or compete with wild insect species, contributing to the loss of biodiversity (Canelles et al., 2021; Evans, 2021; Russo et al., 2021) as well as being of great epidemiological importance, due to several insect-borne diseases, such as malaria, Chagas' disease, dengue, West Nile fever, chikungunya and zika (Bradshaw et al., 2016; WHO, 2020).

The use of synthetic insecticides proved to be of great importance for the control of insect-borne diseases and agricultural pests, which allowed an increase in the quality and productivity of several crops and brought many benefits for mankind (Cooper e Dobson, 2007; Aktar et al., 2009; Assey, Mgohamwende, Malasi, 2021; Tudi et al., 2021). However, the use of these pesticides is also associated with several problems, including the selection of pesticide resistant insects (Sparks et al., 2019), making it difficult to control vectors of pathogenic organisms and leading to the emergence or re-emergence of mosquito-borne diseases (Dahmana, Mediannikov, 2020); effects on nontarget species, negatively affecting parameters such as survival, reproduction and growth (Gustone et al., 2021); and cases of humans' intoxication, for example, it is estimated that poisoning by organophosphate insecticides causes two million hospitalizations per year (Eddleston, 2020).

These results indicate a great need for the development of new strategies to combat insects that act as pests, and several researches have been developed with the aim of finding substitutes for synthetic insecticides, such as the application of suppression and replacement of the insect population (Leftwich et al., 2016) or the use of biopesticides, e.g. products of microbiological origin and botanical insecticides (Glare et al., 2012; Miresmailli e Isman, 2014).

Botanic insecticides are natural products derived from plants used for pest control (Isman et al.,
2011; FAO and WHO, 2017) and among the botanical insecticides most studied for the control of insect pests are the essential oils (RegnaultRoger et al., 2012; Ootani et al., 2013; Miresmailli e Isman, 2014). Brazil, thanks to its diverse flora, has a vast field for its exploration, being one of the countries that lead research in this area (Miresmailli e Isman, 2014; Isman, 2015).

In recent years, several publications have described nanometric systems based on chitosan and essential oils with insecticidal activity. However, although the number of articles describing the preparation and characterization of these nanoparticles is significant, it was observed that the number of publications reporting in vivo insecticidal tests with essential oils loaded chitosan nanoparticles is small, being focused on the control of mosquito larvae (Paula et al., 2010; Abreu et al., 2012; González et al., 2017; Ferreira et al., 2019; Wong et al., 2020), adult beetles (Ziaee et al. 2014a; Ziaee et al. 2014b; Upadhyay et al., 2019; Rajkumar, et al. 2020a; Rajkumar, et al. 2020b) and moth larvae (Campos et al., 2018).

The aim of this review was to present all in vivo tests carried out to evaluate the insecticidal activity of chitosan-based nanoparticles and essential oils, published in scientific articles. The search was carried out in the Scopus database combining the terms "chitosan", "nanoparticle", "essential oil", "insect*", "larv*" and "pest*", and only articles describing in vivo toxicity test against insects, using chitosan-based nanoparticles with essential oils or their isolated components, were selected. For a better understanding, the discussion of the results extracted from the selected articles was preceded by a brief comment on essential oils and chitosan.

\section{ESSENTIAL OILS}

Essential oils are volatile oils of complex composition obtained from plant by hydrodistillation, steam distillation, dry distillation or cold pressing (Regnault-Roger et al., 2012; Asbahani et al., 2015; Pavela, 2015) and find applications in various industrial sectors, such as food industries (Calo et al., 2015), medicines (Raut e Karuppayil, 2014) and cosmetics (Abelan et al., 2021; Sharmeen et al., 2021). They have many characteristics which give them great potential for use as insecticides, since, with rare exceptions, essential oils and their main constituents are relatively non-toxic to mammals, with acute oral $\mathrm{LD}_{50}$ values in rodents higher than $2,000 \mathrm{mg} \mathrm{kg}^{-1}$ for the pure compounds and $5,000 \mathrm{mg} \mathrm{kg}^{-1}$ for formulated products (Isman et al., 2011; RegnaultRoger et al., 2012; Upadhyay et al., 2019).

Their composition consists of a mixture of secondary metabolites that have several 
mechanisms of action and act in a synergistic way, making difficult the appearance of resistant insects (Rattan, 2010; Regnault-Roger et al., 2012). And their half-lives in the environment are shorter than $24 \mathrm{~h}$ (Isman et al., 2011; Regnault-Roger et al., 2012). This high volatility is due to its chemical composition, formed mostly by terpenes and terpenoids (Lammari et al., 2021; Sharmeen et al., 2021; Sharma et al., 2021).

Essential oils can also be used for pest control in stored products (Yang et al., 2009; Melo et al., 2011; González et al., 2014) and insects responsible for the transmission of various diseases, including Aedes aegypti, responsible for the transmission of dengue, zika and chicungunha, Culex quinquefasciatus, responsible for the transmission of West Nile fever and filariasis, and Anopheles gambiae, responsible for the transmission of malaria (Tchoumbougnang et al., 2009; Aguiar et al., 2015; Pavela, 2015; Govindarajan e Benelli, 2016; Mendes et al. 2017). Here it is worth noting that a survey carried out in 2016 estimated that $99 \%$ of the costs of health problems caused by insects are related to dengue and Nile fever (Bradshaw et al., 2016).

Although the essential oils have several promising characteristics, their volatility, easy oxidation and low thermal stability (Turek e Stintzing, 2013) require a high number of applications for pest control to occur satisfactorily. In addition, they can be phytotoxic if used improperly (Amri et al., 2013; Sarmento-Brum et al. 2014). However, such disadvantages can be solved by encapsulating the essential oils (Majeed et al., 2015; Pavela, 2016).

The use of nanometric systems to encapsulate synthetic pesticides has already been studied and the benefits obtained include the increase in efficacy due to the higher surface area of the release system and better systemic activity on the target pest provided by the reduced particle size, besides the decrease toxicity due to the elimination of organic solvents from conventional formulations of pesticides (Ghormade et al., 2011; Rodrigues et al., 2016).

In the case of essential oils, the encapsulation in nanometric systems, such as lipid and polymerbased nanocarriers (Lammari et al., 2021) avoids their evaporation and rapid degradation, improving the stability of the oils, which allows the use of a minimum concentration during the application. And the polymers are among the materials most described in the literature for the encapsulation of essential oils aiming their application as insecticides (Ghormade et al, 2011; Asbahani et al., 2015; Campos et al., 2015; González et al., 2015; González et al., 2016).

\section{CHITOSAN}

The choice of material that will be used for the preparation of the essential oil carriers must take into account some information, such as the environment where the formulation will be applied and how long it must remain active. For example, when developing a formulation aiming at an insecticidal activity in an aqueous medium, it should improve the apparent solubility/miscibility of the essential oil in water. In this case, solid lipid nanoparticles and nanostructured lipid carriers are not suitable due to their intrinsically hydrophobic nature.

Liposomes and nanoemulsions are suitable for making hydrophobic active ingredients compatible with an aqueous medium. However, the first ones have a lower load capacity for hydrophobic active ingredients, due to their hydrophilic core. Regarding nanoemulsions, the changes that occur in the volume and composition of their continuous phase, if they are used in field applications, can lead to changes in the interactions between the nanoemulsion components, destabilizing them and causing coalescence and Ostwald ripening (Nazarzadeh et al., 2013).

For the preparation of polymeric nanoparticles, the techniques and materials used can be chosen to have a high loading capacity while maintaining good compatibility with the aqueous medium. Furthermore, the use of preparation techniques that explore the formation of cross-links between polymer chains allow to obtain systems that present greater stability against environmental variations.

Among the polymers chitosan is considered a promising carrier due to be a natural polymer, biodegradable and with low cost (Campos et al., 2015). Chitosan is a water insoluble polysaccharide, produced naturally by some fungi and obtained on large scale from chitin, the main component of the exoskeleton of crustaceans, being classified as a polycation, acquiring positive charges and solubilizing when in aqueous acid medium (Bellich, D'Agostino, Semeraro e Gamini, 2016; Elsoud e Kady, 2019; Marques et al., 2020). In addition to being a biodegradable polymer, chitosan is biocompatible and the products resulting from its degradation are non-toxic, nonimmunogenic and non-carcinogenic (Canella e Garcia, 2001; Hamed, Ozogul e Regenstein, 2016).

It is a copolymer formed by mers of $N$-acetylglucosamine and glucosamine distributed randomly along its chains. Its segments containing acetylated mers can interact in a non-covalent way with hydrophobic molecules, which facilitates the incorporation of these molecules into chitosanbased nanoparticles and gives these nanoparticles a high load capacity. This interaction with 
hydrophobic molecules can be enhanced by modifying their amino groups, as shown in the next section.

Moreover, the presence of amino groups gives chitosan interesting characteristics. They can be used to prepare crosslinked nanoparticles, which will also be described in the next section, thus obtaining more stable nanoparticles with a high capacity to prolong the insecticidal activity of essential oils, as will be shown in the discussion of bioassays. And these amino groups can be used to maintain the stability of chitosan-based nanoparticle colloidal suspensions during storage.

Chitosan is also widely used together with polyanions to improve their properties, as chitosanbased nanoparticles, in addition to the advantages of increased surface area and ease of absorption that occur due to the nanometric dimensions, are mucoadhesive (Hejjaji et al., 2018) and have the property of opening tight junctions, increasing absorption (Vllasaliu et al., 2010).

\section{CHITOSAN NANOPARTICLES PREPARATION}

It is possible to find in the literature articles describing the in vivo insecticidal activity of essential oils encapsulated in nanoparticles made of chitosan (González et al., 2017; Ferreira et al., 2019; Upadhyay et al., 2019; Rajkumar, et al. 2020a; Rajkumar, et al. 2020b), chitosan derivatives (Ziaee et al. 2014a; Ziaee et al. 2014b), and by combining chitosan with other polysaccharides (Paula et al., 2010; Abreu et al., 2012; Campos et al., 2018; Wong et al., 2020).

As chitosan is only soluble in an aqueous acidic medium, in the vast majority of cases a diluted solution of acetic acid is used to dissolve it. Usually, the essential oil is incorporated during the preparation of chitosan nanoparticles. For this, the oil is emulsified into the chitosan solution with aid of a surfactant, like polysorbate 80 (Paula et al., 2010; Abreu et al., 2012; González et al., 2017; Campos et al., 2018; Ferreira et al., 2019; Upadhyay et al., 2019; Rajkumar, et al. 2020a; Rajkumar, et al. 2020b) or polysorbate 20 (Wong et al. 2020). On the other hand, there are works that make the incorporation of the essential oil into previously prepared and isolated nanoparticles (Ziaee et al. 2014a; Ziaee et al. 2014b).

After formation of the nanoparticles, the obtained suspension can be directly used (Campos et al., 2018) or they can be separated from the medium by techniques such as centrifugation (Ziaee et al. 2014b; González et al., 2017; Upadhyay et al., 2019; Rajkumar et al. 2020a; Rajkumar et al. 2020b; Wong et al., 2020) or spray drying (Paula et al., 2010; Abreu et al., 2012;
Ferreira et al., 2019).

\section{Complex coacervation}

In this technique, a solution of chitosan or chitosan derivative that maintains the characteristic of polycation, is mixed with a solution of an anionic polysaccharide, like angico gum (Paula et al., 2010), cashew gum (Abreu et al., 2012) or arabic gum (Campos et al., 2018), forming complexes due to the interaction between opposing charges. The addition of the essential oil can occur before (Campos et al., 2018) or after (Paula et al., 2010; Abreu et al., 2012) the polyelectrolyte complex formation.

Coacervates obtained by this technique and dried by spray drying provided nanoparticles with diameter less than $100 \mathrm{~nm}$ and unimodal distribution (Table 1). It was also observed that the amount of encapsulated oil can affect the size of the nanoparticles, the increase in the amount of essential oil added during preparation increases the size of the nanoparticles (Paula et al., 2010).

\section{Self-assembly using amphiphilic chitosan}

Nanogels were obtained by the technique of selfassembly using chitosan modified with myristic acid, a saturated 14-carbon fatty acid, to obtain an amphiphilic chitosan that can self-associate, forming micelle-like nanogels with hydrophobic core and hydrophilic shell (Ziaee et al., 2014a; Ziaee et al., 2014b).

They were prepared by precipitation after the reaction between chitosan and myristic acid. The essential oils were added to suspensions of this nanogel in an aqueous acidic solution and sonicated for 30 minutes, being incorporated into their hydrophobic cores. These nanogels have irregular form and diameter between 20 and $250 \mathrm{~nm}$, depending on the type and concentration of encapsulated oils (Ziaee et al. 2014a; Ziaee et al. 2014b) (Table 1).

\section{Crosslinked chitosan}

To obtain nanoparticles using a crosslinking agent, a solution of chitosan is mixed with a solution of the crosslinking agent, for example, sodium tripolyphosphate (TPP) (González et al., 2017; Upadhyay et al., 2019; Rajkumar, et al. 2020a; Rajkumar, et al. 2020b) or glutaraldehyde (Ferreira et al., 2019). The essential oil is emulsified in the polymeric solution before mixing with the crosslinking agent.

Crosslinking with TPP is called ionic gelation, because crosslinking occurs due to interactions of the positively charged chitosan amino groups with the negatively charged phosphate groups. The $\mathrm{pH}$ of the medium affects the density of the crosslink, 
increasing the $\mathrm{pH}$ decreases this density by decreasing the number of protonated amino groups available for the crosslinking (Bhumkar, Pokharkar, 2006).

In the case of glutaraldehyde, it reacts by forming a covalent bond with the amino groups of chitosan, and it is important to control the $\mathrm{pH}$ of the reaction medium between 4 and 5 in order to shift the balance towards the formation of the imine group. In both cases the crosslinking agent acts by making crosslinks between different parts of the same polymeric chain or between different chains (Islam, Dmour e Taha, 2019). However, Dmour and Taha (2017) observed that ionically crosslinked nanoparticles were less stable at $\mathrm{pH}$ variations than those covalently crosslinked. This also was observed by Paulraj et al. (2017) when encapsulating PONNEM, a botanical insecticide based in neem and karanj oils, into chitosan nanoparticles.

Table 1 - Effect of preparation conditions on the physical properties of chitosan nanoparticles loaded with essential oils.

\begin{tabular}{|c|c|c|c|c|c|c|}
\hline $\begin{array}{l}\text { Preparation tech- } \\
\text { nique }\end{array}$ & $\begin{array}{l}\text { Chitosan: } \\
\text { polyanion } \\
\text { ratio } \\
(\mathbf{m}: \mathbf{m}) \\
\end{array}$ & $\begin{array}{l}\text { Polymer: essential oil ra- } \\
\text { tio used during prepara- } \\
\text { tion } \\
(\mathrm{m}: \mathrm{m})\end{array}$ & $\begin{array}{l}\text { Average di- } \\
\text { ameter (nm) }\end{array}$ & PDI & $\begin{array}{l}\text { Zeta poten- } \\
\text { tial }(\mathrm{mV})\end{array}$ & Reference \\
\hline \multicolumn{7}{|l|}{$\begin{array}{c}\text { Complex coacer- } \\
\text { vation } \\
\end{array}$} \\
\hline $\begin{array}{l}\text { Chitosan / angico } \\
\text { gum / spray drier }\end{array}$ & $1: 10$ & $\begin{array}{c}2.2: 1-22: 1 \text { (Lippia si- } \\
\text { doides) }\end{array}$ & $12-37$ (DLS) & $\begin{array}{c}0.330- \\
1.000 \\
\end{array}$ & $-14--21$ & $\begin{array}{l}\text { Paula et al., } \\
2010\end{array}$ \\
\hline $\begin{array}{l}\text { Chitosan / cashew } \\
\text { gum / spray drier }\end{array}$ & $1: 10$ & $1: 5($ L. sidoides $)$ & 551 (DLS) & 0.554 & +4 & $\begin{array}{l}\text { Abreu et al., } \\
2012\end{array}$ \\
\hline \multicolumn{7}{|l|}{$\begin{array}{c}\text { Self-assembly of } \\
\text { chitosan derivatives }\end{array}$} \\
\hline $\begin{array}{c}\text { Chitosan-myristic } \\
\text { acid }\end{array}$ & - & $4.2: 1$ (Carum copticum) & $\begin{array}{l}133 \text { (DLS) } \\
150 \text { (SEM) }\end{array}$ & $\begin{array}{l}\text { Not deter- } \\
\text { mined }\end{array}$ & $\begin{array}{l}\text { Not deter- } \\
\text { mined }\end{array}$ & $\begin{array}{c}\text { Ziaee et al. } \\
2014 \mathrm{~b}\end{array}$ \\
\hline \multicolumn{7}{|l|}{$\begin{array}{c}\text { Covalent crosslink- } \\
\text { ing }\end{array}$} \\
\hline $\begin{array}{c}\text { Chitosan / glutaral- } \\
\text { dehyde }\end{array}$ & - & $1: 2$ (Siparuna guianensis) & 82 (SEM) & $\begin{array}{l}\text { Not deter- } \\
\text { mined }\end{array}$ & $\begin{array}{l}\text { Not deter- } \\
\text { mined }\end{array}$ & $\begin{array}{l}\text { Ferreira et } \\
\text { al., } 2019\end{array}$ \\
\hline \multicolumn{7}{|l|}{ Ionic gelation } \\
\hline Chitosan / TPP & - & $\begin{array}{c}1: 2(\text { Geranium macula }- \\
\text { tum })\end{array}$ & 439 (DLS) & 0.358 & $\begin{array}{l}\text { Not deter- } \\
\text { mined }\end{array}$ & $\begin{array}{c}\text { González et } \\
\text { al., } 2017 \\
\end{array}$ \\
\hline Chitosan / TPP & - & $1: 2$ (Citrus bergamia) & 535 (DLS) & 0.379 & $\begin{array}{l}\text { Not deter- } \\
\text { mined }\end{array}$ & $\begin{array}{c}\text { González et } \\
\text { al., } 2017 \\
\end{array}$ \\
\hline Chitosan / TPP & - & $1: 2$ (Piper nigrum) & 527 (DLS) & & -5 & $\begin{array}{l}\text { Rajkumar, et } \\
\text { al. 2020a }\end{array}$ \\
\hline Chitosan / TPP & - & $1: 2$ (Mentha X piperita) & 564 (DLS) & & -12 & $\begin{array}{c}\text { Rajkumar et } \\
\text { al., 2020b }\end{array}$ \\
\hline $\begin{array}{l}\text { Alginate / } \mathrm{Ca}^{2+} \\
\text { (core) } \\
\text { Chitosan (shell) }\end{array}$ & & $\begin{array}{c}50: 1-150: 1 \text { (cinnamal- } \\
\text { dehyde) }\end{array}$ & $\begin{array}{c}55-103 \\
(\mathrm{TEM})\end{array}$ & & $\begin{array}{l}\text { Not deter- } \\
\text { mined }\end{array}$ & $\begin{array}{l}\text { Wong et al., } \\
2020\end{array}$ \\
\hline
\end{tabular}

PDI: Polydispersion index; DLS: Dynamic light scattering; SEM: Scanning electron microscopy; TPP: Tripolyphosphate.

\section{Other techniques}

Alginate nanoparticles coated with chitosan were prepared by emulsifying the essential oil in an alginate solution, followed by crosslinking the alginate with $\mathrm{Ca}^{2+}$ ion and coating the nanoparticles formed with chitosan. The crosslinking of the alginate occurs by the interaction between the negative charges of $\mathrm{COO}^{-}$along the alginate chains and the positive charges of $\mathrm{Ca}^{2+}$. Chitosan can interact with the negative residual charges on the surface of these nanoparticles, forming a coating on them (Wong et al., 2020).

From the average diameter values for nanoparticles obtained by various techniques and different proportions of essential oil in relation to the amount of polymer used in the preparation, it is observed that there is a tendency to increase the size of the nanoparticles when increasing the proportion of essential oil during the nanoparticle preparation and that the technique of preparation by polyelectrolyte complexes is the one that produces nanoparticles with smaller size. This preparation technique also stands out for producing nanoparticles with unimodal size distribution (Table 1). This decrease in size corresponds to an increase in the total surface area, which increases the contact of nanoparticles with surfaces and facilitates their cellular uptake. 


\section{INSECTICIDAL ACTIVITY BIOASSAYS}

It was found that the toxicity tests described in the publications selected for this review evaluated the insecticidal activity of chitosan-based nanoparticles containing essential oils against mosquito larvae, caterpillars and adult beetles.

\section{Tests against mosquito larvae}

Bioassays against mosquito larvae, in general, were done by placing the larvae in containers with water and nanoparticles. The larvae used were from the third or four instars and the number of larvae tested varied from 5 to 25 (Table 2) (Paula et al., 2010; Abreu et al., 2012; González et al., 2017; Ferreira et al., 2019; Wong et al., 2020).

A Brazilian research group was one of the pioneers in the in vivo evaluation of the insecticidal activity of essential oils encapsulated in chitosan nanoparticles. They evaluated nanoparticles obtained by the formation of polyelectrolyte complexes between chitosan and polysaccharides with anionic charges against mosquito larvae (Paula et al., 2010; Abreu et al., 2012).

Paula et al. (2010) encapsulated Lippia sidoides essential oil into nanoparticles of chitosan complexed with angico gum (a polysaccharide with negative charges) and performed bioassays against Ae. aegypti for 3 days. They observed that, in the time interval analyzed, the $L$. sidoides essential oil encapsulated inside the nanoparticles maintains the larvicide effect and reaches mortality rates from $52 \%$ to $92 \%$ and comments that this result is compatible with that obtained with pure oil, although the authors do not show any result with the oil alone, so that one can't verify which increase in the half-life of the oil in solution is obtained with the nanoparticles.

At first these results are disheartening. This lack of details and the superficial discussion found in this first article can be attributed to the incipience of researchers in the field of chemistry and materials engineering when taking the first steps towards a biological assay. And the results of this session were placed in chronological order so that it is possible to observe the advances regarding the structuring of research and discussion of the results as new research were developed at the interface between the material and biological areas.

The same work group (Abreu et al., 2012) done biological assays using $L$. sidoides essential oil loaded in nanoparticles from chitosan-cashew gum (negatively charged polysaccharide) polyelectrolyte complexes against third instar Ae. aegypti larvae. As expected, an increase in the proportion of encapsulated essential oil increased larval mortality. They obtained $100 \%$ mortality using $0.48 \mathrm{mg}$ $\mathrm{mL}^{-1}$ of nanoparticles made with the ratio of chitosan / cashew gum of 1:10, in an interval of $24 \mathrm{~h}$. Considering the loading of this nanoparticle, this concentration is equivalent to an essential oil concentration in the medium of $39 \mathrm{ppm}$ (Table 2).

Table 2 - Comparison between the physicochemical properties and the larvicidal activity of chitosan nanoparticles loaded with essential oils.

\begin{tabular}{|c|c|c|c|c|c|c|}
\hline $\begin{array}{c}\text { Anionic polysac- } \\
\text { charide or cross- } \\
\text { linking agent / Es- } \\
\text { sential oil }\end{array}$ & Insect & $\begin{array}{c}\text { Nanoparticle } \\
\text { concentration } \\
\left(\mathbf{m g ~ m L} \mathbf{~ L ~}^{-1}\right)\end{array}$ & $\begin{array}{l}\text { Oil concen- } \\
\text { tration (ppm) }\end{array}$ & $\begin{array}{c}\text { Acute* test } \\
\text { mortality } \\
(\%)\end{array}$ & $\begin{array}{l}\text { Residual** } \\
\text { toxicity dura- } \\
\text { tion above } \\
\mathbf{8 0 \%} \text { (days) }\end{array}$ & Reference \\
\hline $\begin{array}{c}\text { Angico gum / Lippia } \\
\text { sidoides }\end{array}$ & $\begin{array}{c}3^{\circ} \text { instar Aedes ae- } \\
\text { gypti }\end{array}$ & 1.00 & $34-63$ & 85 & Not determined & $\begin{array}{c}\text { Paula et al., } \\
2010\end{array}$ \\
\hline $\begin{array}{c}\text { Cashew gum / L. si- } \\
\text { doides }\end{array}$ & $\begin{array}{c}3^{\circ} \text { instar Ae. ae- } \\
\text { gypti }\end{array}$ & 0.48 & 39 & 100 & Not determined & $\begin{array}{l}\text { Abreu et al., } \\
2012\end{array}$ \\
\hline $\begin{array}{c}\text { TPP / Geranium ma- } \\
\text { culatum }\end{array}$ & $\begin{array}{c}4^{\mathrm{o}} \text { instar Culex pi- } \\
\text { piens } \\
\end{array}$ & 0.19 & 82 & 100 & 4 & $\begin{array}{l}\text { González et } \\
\text { al., (2017) }\end{array}$ \\
\hline $\begin{array}{c}\text { TPP / Citrus berga- } \\
\text { mia }\end{array}$ & $\begin{array}{c}4^{\circ} \text { instar Cx. pipi- } \\
\text { ens }\end{array}$ & 0.28 & 87 & 100 & 4 & $\begin{array}{l}\text { González et } \\
\text { al., (2017) }\end{array}$ \\
\hline $\begin{array}{l}\text { Glutaraldehide / Si- } \\
\text { paruna guianensis }\end{array}$ & $\begin{array}{c}3^{\circ} \text { instar } A e . a e- \\
\text { gypti }\end{array}$ & $0.83-6.67$ & $500-4000$ & 100 & 14 & $\begin{array}{l}\text { Ferreira et } \\
\text { al., (2019) }\end{array}$ \\
\hline $\begin{array}{c}* * * \mathrm{Ca}^{2+} / \text { cinnamal- } \\
\text { dehyde }\end{array}$ & $\begin{array}{c}3^{\circ} \text { instar } A e . a e- \\
\text { gypti }\end{array}$ & 14.28 & 11626 & 20 & Not determined & $\begin{array}{c}\text { Wong et al., } \\
(2020)\end{array}$ \\
\hline
\end{tabular}

TPP: Tripolyphosphate. *Tests in which the mortality was assessed within 24 hours. **Testes in which the larvae were replaced daily and, at each replacement the mortality was measured. $* * *$ Alginate core revested with chitosan.

It is important to note that not only the concentration of materials, but also the preparation methodology made difference in larval mortality. The sample with the greatest encapsulation efficiency and, consequently, the highest oil concentration in the medium (53 $\mathrm{ppm}$ ) reached a mortality rate of only $60 \%$ in $24 \mathrm{~h}$. To prepare this sample, a cashew gum solution with a concentration of $5 \%$ was used. For the sample that obtained $100 \%$ mortality in 24 $\mathrm{h}$, the same proportion between the mass of 
chitosan and the mass of the cashew gum was maintained, but a $10 \%$ cashew gum solution was used (Abreu et al., 2012).

One hypothesis to explain these results is that the viscosity of the polyanion solution positively influenced the final properties of these nanoparticles, in order to obtain the best toxic result within $24 \mathrm{~h}$. The article describes that their sizes were $405 \pm 52 \mathrm{~nm}$ (sample prepared with 5\%) and $551 \pm 106 \mathrm{~nm}$ (sample prepared with $10 \%$ ), but the authors did not determine the morphology or zeta potential of the particles, hindering a further exploration of the relationship between mortality and physical and physical-chemical properties of nanoparticles (Abreu et al., 2012).

González and co-works (2017) used four instar larvae of Culex pipiens in bioassays performed with chitosan nanoparticles crosslinked with TPP and loaded with Geranium maculatum or Citrus bergamia essential oils. They done acute and residual tests and used two controls in these tests, only water and water plus chitosan nanoparticles without essential oil. The temperature and relative humidity were controlled in all experiments.

From results they calculated the $\mathrm{LC}_{50}$ and $\mathrm{LC}_{99}$, that were respectively 22 and $81 \mathrm{ppm}$ to G. $\mathrm{macu}$ latum and 38 and $87 \mathrm{ppm}$ to $C$. bergamia, when these essential oils are encapsulated in chitosan nanoparticles, verifying that the mortality obtained in the first $24 \mathrm{~h}$ for nanoparticles was higher than the one observed to the pure oils. However, the nanoparticles produced in this work were only able to maintain the residual activity of essential oils in the first days (Table 2). The larvicidal activity of the nanoparticles declined rapidly, decreasing to less than 50\% in one week (González et al., 2017).

Another bioassay against third instar Ae. aegypti larvae was made by Ferreira et al. (2019). Using only Siparuna guianensis essential oil or chitosan nanoparticle crosslinked with glutaraldehyde added to the water, no death of the exposed larvae was observed, while using the essential oil encapsulated into these nanoparticles, at the same concentration, $100 \%$ mortality was obtained.

When comparing mortality in an interval of 24 $\mathrm{h}$, for the same concentration of essential oil in the medium, but using nanoparticles prepared with three proportions between chitosan and essential oil, $2: 1,1: 1$ and $1: 2$, they observed that the increase in the proportion of essential oil leads to an increase in mortality, reaching $100 \%$ in the greatest proportion (Ferreira et al., 2019). These results are in line with the results described earlier (Abreu et al., 2012).

They also evaluated the maintenance of this toxic effect for a period of 19 days. In this trial, dead larvae were counted daily and then all larvae (live or dead) have been replaced by new larvae, to check whether the residual toxicity of the nanoparticles in the medium remained constant. It was possible to find that mortality remained at $100 \%$ for one week and declined, reaching $80 \%$ in two weeks (Table 2) (Ferreira et al., 2019).

Toxicity tests of cinnamaldehyde, one of the components of essential cinnamon oil, encapsulated in alginate nanoparticles coated with chitosan, were performed against Ae. aegypti larvae. In these tests, water and temephos were used as negative and positive controls, respectively. The acute toxicity of these nanoparticles was low (Table 2). In subacute toxicity tests, $100 \%$ mortality was achieved with a concentration of nanoparticles equivalent to 3,279 ppm cinnamaldehyde and 96 hours of exposure, while this mortality rate was reached within 72 hours when using temephos (Wong et al., 2020).

Table 2 summarizes the main results obtained for tests carried out with mosquito larvae. The best results in acute toxicity tests were observed for the oil of $L$. sidoides encapsulated in nanoparticles of chitosan complexed with cashew gum. These particles had a diameter of approximately $500 \mathrm{~nm}$ and a zeta potential of +4 . However, its efficiency in maintaining the residual toxicity of essential oil for an extended period of time has not been evaluated. Among the nanoparticles that had their ability to maintain the residual toxicity of essential oils evaluated, the ones that showed the best performance were the chitosan nanoparticles cross-linked with glutaraldehyde, containing $S$. guianensis essential oil.

In addition to testing the larvicidal activity of nanoparticles loaded with essential oils, it would be important to observe the toxicity on the development and reproduction of mosquitoes.

\section{Tests against adult beetles}

Fumigant toxicity tests were performed using 20 to 25 beetles 4-14 days old and of mixed sex, which were placed into vials with lids. The tests were done with replicates, and with control groups that were exposed only to unloaded nanoparticles or acetone (Ziaee et al., 2014a; Ziaee et al., 2014b; Upadhyay et al., 2019; Rajkumar, et al. 2020a; Rajkumar, et al. 2020b).

Ziaee et al. (2014a and 2014b) described bioassays to determine the toxicity of Cuminum cyminum and Carum copticum essential oils-loaded chitosan nanogels against adults of Sitophilus granarius and Tribolium confusum, two pests that attack cereal grains and are common in temperate regions. The percentage of mortality obtained for the encapsulated oils was higher than that of pure oils for all the analyzed concentrations and no 
mortality was observed in the control group, which indicates that only chitosan nanogel has no fumigant activity.

They also compared the persistence of pure oil and encapsulated oil and observed that the oilloaded nanogels remained effective for up to 18 days, while the essential oil lost its insecticidal potential in a short period of time (Ziaee et al. 2014a; Ziaee et al. 2014b). These results can be explained by the affinity of the essential oil components, which are hydrophobic, for the myristic acid grafted along the chitosan chains. In this way, the essential oil is slowly released from the chitosan-based nanogels, while the components of the pure oil are quickly volatilized and degraded. Ziaee et al. (2014b) also determined the $\mathrm{LC}_{50}$ of the C. copticum essential oil and the loaded nanogel and observed that this last has a $\mathrm{LC}_{50}$ lower than that of the pure essential oil for both beetles (Table 3). This effect may be related to the components of the oil that remained trapped in the nanoparticles, as an increase in the proportion of thymol was observed, in relation to the other components of the essential oil of C. copticum.

Table 3 - Lethal concentrations of essential oils (EO) and essential oils loaded nanoparticles (EOLN) after 24 $\mathrm{h}$ of exposure.

\begin{tabular}{|c|c|c|c|}
\hline Insect pest & Sample & $\mathbf{L C}_{50}\left(\mu \mathrm{L} \mathrm{L}^{-1}\right)$ & Reference \\
\hline \multirow{2}{*}{ Sitophilus granarius } & Carum copticum EO & 14 & \multirow{4}{*}{ Ziaee et al., 2014b } \\
\hline & C. copticum EOLN & 4.6 & \\
\hline \multirow{2}{*}{ Tribolium confusum } & C. copticum $\mathrm{EO}$ & 47 & \\
\hline & C. copticum EOLN & 14 & \\
\hline \multirow{2}{*}{ Tribolium castaneum } & Melissa officinalis EO & 71 & \multirow{2}{*}{ Upadhyay et al., 2019} \\
\hline & M. officinalis EOLN & 48 & \\
\hline \multirow{2}{*}{ T. castaneum } & Piper nigrum EO & 56 & \multirow{4}{*}{ Rajkumar et al., 2020a } \\
\hline & P. nigrum EOLN & 29 & \\
\hline \multirow{2}{*}{ Sitophilus oryzae } & P. nigrum EO & 49 & \\
\hline & P. nigrum EOLN & 25 & \\
\hline \multirow{2}{*}{ T. castaneum } & Mentha X piperita EO & 63 & \multirow{4}{*}{ Rajkumar et al., 2020b } \\
\hline & M. piperita EOLN & 35 & \\
\hline \multirow{2}{*}{ S. oryzae } & M. piperita $\mathrm{EO}$ & 56 & \\
\hline & M. piperita EOLN & 29 & \\
\hline
\end{tabular}

The characteristics of the nanoparticles and the mortalities obtained for each oil and each species tested are summarized in Table 4. From the data shown in Table 4, it is possible to observe that the maintenance of residual fuming toxicity above $80 \%$ is not the same for the two insect species. This can be attributed to the sensitivity of each of the insects tested to the components of the essential oils that remain in the nanoparticles longer.

Probably the most volatile components of these oils are more toxic to $S$. granarius. Its faster release leads to greater acute toxicity for this species, however, with the reduction of its concentration, the residual toxicity lasts for a few days. The opposite is observed for $T$. confusum, which was less sensitive to the more volatile components of essential oil, with less mortality in the acute toxicity test, but being more sensitive to less volatile components, which become the predominant components throughout the residual toxicity test.

The fumigant toxicity and antifeedant activity of the Melissa officinalis essential oil encapsulated in chitosan nanoparticles against adults of Tribolium castaneum were also evaluated. This insect is a pest related to the deterioration of wheat flour and
Upadhyay et al. (2019) verified that the essential oil of M. officinalis had a toxic effect on it, causing oxidative stress due to the increase in reactive oxygen species (ROS). In the literature it is possible to find articles reporting the occurrence of cell death by the formation of ROS induced by the essential oil and by the extract of $M$. officinales (Queiroz et al., 2014; Weidner et al., 2015), as well as that its essential oil may also have an antioxidant activity (Abdellatif et al., 2021; Radulescu et al, 2021). These conflicting results could be due to variation in the composition of essential oils used in these studies.

It was observed that the encapsulation of the essential oil of $M$. officinalis in the chitosan nanoparticles decreased the $\mathrm{LC}_{50}$ value (Table 3 ) and no mortality was observed in the control groups with water or nanoparticles without essential oil (Upadhyay et al., 2019). This decrease in the $\mathrm{LC}_{50}$ value in relation to non-encapsulated oil is in line with what was previously observed by Ziaee et al. (2014b).

The antifeedant activity was done by the flour disk bioassay, using the sublethal concentrations $\mathrm{LC}_{20}, \mathrm{LC}_{30}, \mathrm{LC}_{40}$ and $\mathrm{LC}_{50}$ determined in the 
fumigant bioassay. It was possible to achieve a feed deterrence of $8 \%, 25 \%, 70 \%$ and $80 \%$, according to the tested sublethal concentration (Upadhyay et al., 2019).

Table 4 - Comparison between the fumigant toxicity of chitosan nanoparticles loaded with essential oils.

\begin{tabular}{|c|c|c|c|c|c|c|}
\hline $\begin{array}{c}\text { Essential } \\
\text { oil }\end{array}$ & $\begin{array}{l}\text { Averange di- } \\
\text { ameter (nm) }\end{array}$ & Insect & $\begin{array}{l}\text { Oil concentra- } \\
\text { tion }\left(\mu \mathrm{L} \mathrm{L}^{-1} \text { air }\right)\end{array}$ & $\begin{array}{l}\text { Acute test* } \\
\text { mortality } \\
(\%)\end{array}$ & $\begin{array}{l}\text { Residual toxicity** } \\
\text { duration above } 80 \% \\
\text { (days) }\end{array}$ & Reference \\
\hline \multirow{2}{*}{$\begin{array}{l}\text { Cuminum } \\
\text { cyminum }\end{array}$} & \multirow{2}{*}{$20-70(\mathrm{DLS})$} & $\begin{array}{c}\text { 7-14 days } \\
\text { Sitophilus gran- } \\
\text { arius } \\
\end{array}$ & 16 & 97 & 5 & \multirow{2}{*}{$\begin{array}{c}\text { Ziaee et al. } \\
2014 \mathrm{a}\end{array}$} \\
\hline & & $\begin{array}{c}\text { 7-14 days } \\
\text { Tribolium con- } \\
\text { fusum } \\
\end{array}$ & 20 & 61 & 15 & \\
\hline \multirow{2}{*}{$\begin{array}{l}\text { Carum } \\
\text { copticum }\end{array}$} & \multirow{2}{*}{$\begin{array}{l}133 \text { (DLS) } \\
150 \text { (SEM) }\end{array}$} & $\begin{array}{c}\text { 7-14 days } S . \text { gran- } \\
\text { arius }\end{array}$ & 18 & 100 & 3 & \multirow{2}{*}{$\begin{array}{l}\text { Ziaee et al. } \\
2014 \mathrm{~b}\end{array}$} \\
\hline & & $\begin{array}{l}\text { 7-14 days T. con- } \\
\text { fusum }\end{array}$ & 43 & 90 & 13 & \\
\hline \multirow{2}{*}{$\begin{array}{c}\text { Piper } \\
\text { nigrum }\end{array}$} & \multirow{2}{*}{527 (DLS) } & $\begin{array}{c}\text { 4-6 days Sitophilus } \\
\text { oryzae }\end{array}$ & 75 & 100 & Not determined & \multirow{2}{*}{$\begin{array}{c}\text { Rajkumar et } \\
\text { al., 2020a }\end{array}$} \\
\hline & & $\begin{array}{c}\text { 4-6 days Tribolium } \\
\text { castaneum }\end{array}$ & 75 & 100 & Not determined & \\
\hline \multirow{2}{*}{$\begin{array}{c}\text { Mentha } X \\
\text { piperita }\end{array}$} & \multirow[b]{2}{*}{564 (DLS) } & 4-6 days $S$. oryzae & 75 & 100 & Not determined & \multirow[b]{2}{*}{$\begin{array}{c}\text { Rajkumar et } \\
\text { al., 2020b }\end{array}$} \\
\hline & & $\begin{array}{c}\text { 4-6 days } T \text {. casta- } \\
\text { neum }\end{array}$ & 75 & 100 & Not determined & \\
\hline
\end{tabular}

*Tests in which the mortality was assessed within 24 hours; **Testes in which the adults were replaced evey two days and, at each replacement the mortality was measured.

Another research group found that there is an increase in the fumigant toxicity of Piper nigrum and Mentha X piperita essential oils encapsulated in chitosan nanoparticles against $T$. castaneum and $S$. oryzae, when compared with the pure oils, with a reduction in the $\mathrm{LC}_{50}$ values (Table 3 ). The authors also measured the inhibition of the acetylcholinesterase enzyme caused by nanoparticles containing the essential oil of $P$. nigrum or $M$. piperita in the fumigant toxicity tests, verifying that this inhibition is dose-dependent and greater than that caused by the pure essential oils (Rajkumar, et al. 2020a; Rajkumar et al., 2020b).

The evaluation of the antifeeding activity of chitosan nanoparticles loaded with the essential oil of $P$. nigrum was carried out as follows: one hundred adult beetles were placed into vials containing 500 $\mathrm{g}$ of wheat grain and essential oil loaded nanoparticles using the sublethal concentrations $\mathrm{LC}_{20}$ and $\mathrm{LC}_{50}$. The weight loss of wheat grains was measured after 6 months of storage. The feeding deterrent index were $40 \%$ and $100 \%$ for $S$. oryzae and $38 \%$ and $100 \%$ for $T$. castaneum (Rajkumar, et al. 2020a).

\section{Tests against moth larvae}

Campos et al. (2018) analyzed the toxicity of the monoterpenes carvacrol and linalool encapsulated in chitosan nanoparticles against larvae of Helicoverpa armigera. This insect is an agricultural pest and some authors have evaluated its susceptibility to essential oils (Liao et al., 2017; Santos et al., 2017). These monoterpenes act by inhibiting acetylcholinesterase and are found in the essential oils of Thymus vulgaris and Ocimum basilicum, respectively (Campos et al. 2018).

The nanoparticles were obtained by the functionalization of chitosan with $\beta$-cyclodextrin and subsequent complexation with arabic gum (anionic polyssacaride). The bioassays were done by incubating the caterpillars with feeding discs containing the nanoparticles. In the tests, 5 caterpillars were used per disk and mortality was analyzed on the 7th day of incubation. In the control group, water was used instead of nanoparticles (Campos et al., 2018).

The mortality obtained with the nanoparticles containing both compounds for the $H$. armigera caterpillar in the $2^{\circ}$ instar was $86 \%$, being statistically higher than that obtained with an emulsion of these monoterpenes and also of the control group. Unfortunately, these authors do not give information about the concentration of polymeric solutions used in the preparation of nanoparticles, nor about the ratio between the polymers used (Campos et al., 2018).

They also evaluated the effect of carvacrol and linalool loaded into nanoparticles on the pupae of the surviving larvae and observed that they showed a significant decrease in their weight in relation to the control and the group that came into contact with the emulsified oil, showing that these nanoparticles have a growth regulating effect 
(Campos et al., 2018). Another observation that could have been made would be to verify if these nanoparticles have antifeedant activity, as described by Paulraj et al. (2017).

They were able to observe that the residual effect obtained with nanoparticles containing only linalool was not statistically different from the control group (Campos et al., 2018), probably due to its higher vapor pressure, which had been observed previously for the components with higher vapor pressure in the oils from $C$. cyminum and C. copticum (Ziaee et al. 2014a; Ziaee et al. 2014b).

\section{OTHER ASSAYS}

Considering the possible applications of the chitosan-based nanoparticles containing essential oils, the toxicity tests on non-target species and cytotoxicity described in the articles selected for this review are summarized below.

Ferreira et al. (2019) evaluated the acute and residual toxicities of $S$. guianensis loaded chitosan nanoparticles against embryos of Danio rerio and adults of Poecilia reticulata. In first case, they used 10 eggs per concentration. The tests were initiated immediately after fertilization and lasted $96 \mathrm{~h}$, with daily observation of embryos and larvae. The embryos were considered dead if was observed embryo coagulation, lack of somite formation, non-detachment of the tail or lack of heartbeat.

No changes were observed at concentrations less than $0.1 \mathrm{mg} \mathrm{mL}^{-1} .30 \%$ of mortality was reached with the increase in concentration to $0.45 \mathrm{mg} \mathrm{mL}^{-1}$ with no dead in the control at the same concentration. $100 \%$ of mortality was observed with $0.90 \mathrm{mg}$ $\mathrm{mL}^{-1}$ (Ferreira et al., 2019). These results indicate that $\mathrm{LC}_{50}$ of chitosan nanoparticles containing the essential oil of $S$. guianensis is greater than $0.1 \mathrm{mg}$ $\mathrm{mL}^{-1}$ and that they would not be classified as material that presents acute toxicity to the aquatic environment. However, to confirm this indication it is necessary to submit the results to a statistical analysis, in order to accurately determine the $\mathrm{LC}_{50}$ value.

In tests with fish embryos it is important to report the fertilization rate, saying if it was greater than $70 \%$, just as it is important to use a positive control, and to check the hatching percentage of the controls, which must be greater than or equal to $80 \%$. It is also important to measure the dissolved oxygen concentration at the end of the test, which must be greater than or equal to $80 \%$. And inform what is the mortality in the concentration of $0.1 \mathrm{mg} \mathrm{mL}^{-1}$, to be able to tell if the substance falls in the acute category 3 or not classified as acute to the aquatic environment.

Considering that $D$. rerio embryos do not have all metabolic enzymes, and that some substances become more toxic after undergoing biotransformation, the authors also evaluated the toxicity of nanoparticles in adults of $P$. reticulata. The test consisted of placing two adult fish in glass bows containing $0.83 \mathrm{mg} \mathrm{mL}^{-1}$ of nanoparticles. Assessments were made every 24 hours, after which the fish were exchanged to check the residual toxicity of the nanoparticles. This procedure was repeated for 4 days. As control, a suspension of nanoparticles without essential oil was used. Twenty replicates were made for each treatment (Ferreira et al., 2019).

The acute mortality rate in the analyzed concentration was $30 \%$. This corroborates with the results obtained with fish embryos, that the chitosan nanoparticles containing $S$. guianensis essential oil do not present acute toxicity to the aquatic environment. No residual toxicity was observed after 72 hours, which may be related to the release kinetics and the rapid degradation of essential oil in the environment (Ferreira et al., 2019).

Regarding the application of encapsulated essential oils for the control of agricultural pests, it is important to assess whether these nanoparticles will be phytotoxic. Thus, Campos and collaborators (2018) tested the toxicity of chitosan nanoparticles containing linalool and carvacrol using pre- and post-emergence treatments of Zea mays seedlings. They evaluated the lengths of shoots and roots, and the concentration of chlorophylls A and B, and carotenoids. It was possible to verify that the treatments with the nanoparticles obtained by the complexation between chitosan and arabic gum, with and without essential oil, caused an increase in the concentration of chlorophylls A and B and carotenoids. However, the authors do not discuss what could be the causes of this increase.

The lengths of shoots evaluation showed that only the seedlings submitted to post-emergence treatments showed a statistical difference in relation to the control, with a longer shoot length. The length of the roots was affected in the opposite way when the treatment was pre- or post-emergence. In the first case, seeds treated with oil-free nanoparticles had shorter roots than the control, whereas plants treated after emergence with nanoparticles with or without essential oil had longer roots than the control. The authors did not discuss whether the components of the nanoparticles or the products generated by their degradation could act as modulators of plant growth (Campos et al., 2018).

Campos et al. (2018) also evaluated the cytotoxicity of nanoparticles to fibroblasts, noting that cell viability decreases with increasing concentration of chitosan nanoparticles obtained by complexing with arabic gum. All tested nanoparticles led to a 
reduction in cell viability greater than $70 \%$, regardless of the cell line tested, pulmonary fibroblast (V79) or mouse fibroblast (Balb C-3T3). The authors do not discuss whether the observed cytotoxicity would be attributed to chitosan itself, the arabic gum used for complexation or the cyclodextrin grafted onto chitosan.

\section{CONCLUSIONS}

This review provides those interested in the application of essential oils a summary of chitosan nanoparticles production techniques and the performance of these oils transported by nanocarriers, allowing an easy comparison between the results available in the literature. In vivo toxicity tests using insects show that encapsulation of essential oils or their isolated components decreases the $\mathrm{LD}_{50}$, probably because it increases their contact and absorption by insects. As well as promoting greater stability and permanence of these essential oils in the medium, circumventing problems of hydrophobicity, volatility and instability of their components. However, it is seen that the number of publications regarding toxicity against non-target species are still few, demonstrating the need for more research in this regard.

\section{ACKNOWLEDGEMENTS}

To professor Marcio dos S. T. Pinto, Environmental Chemistry Course, Federal University of Tocantins, Gurupi, for the critical reading of this manuscript.

\section{BIBLIOGRAPHIC REFERENCES}

Abdellatif F, Akram M, Begaa S, Messaoudi M, Benarfa A, Egbuna C. Minerals, Essential Oils, and Biological Properties of Melissa officinalis L. Plants, v.10, n.6, 1066, 2021. https://doi.org/10.3390/plants10061066

Abelan US, Oliveira AC, Cacoci ESP, Martins TEA, Giacon VM, Velasco MVR. Potential use of essential oils in cosmetic and dermatological hair products: A review. Journal of Cosmetic Dermatology, v.00, n.00. p.1-12, 2021. https://doi.org/10.1111/jocd.14286

Abreu FOS, Oliveira EF, Paula, HCF, Paula, RCM. Chitosan/cashew gum nanogels for essential oil encapsulation. Carbohydrate Polymer, v.89, n.4, p.1277-1282, 2012. https://doi.org/10.1016/j.carbpol.2012.04.048

Aguiar RWS, Santos SF, Morgado FS, Ascencio SD, Lopes MM, Viana KF et al. Insecticidal and repellent activity of Siparuna guianensis Aubl. (Negramina) against Aedes aegypti and Culex quinquefasciatus. PLoS ONE, v.10 n.2, e0116765, 2015. https://doi.org/10.1371/journal.pone. 0116765
Aktar MW, Sengupta D, Chowdhury A. Impact of pesticides use in agriculture: their benefits and hazards. Interdisciplinary Toxicology, v.2, n.1, p.1-12, 2009. https://doi.org/10.2478/v10102-009-0001-7

Amri I, Hamrouni L, Hananac M, Jamoussi B. Reviews on phytotoxic effects of essential oils and their individual. International Journal of Applied Biology and Pharmaceutical Technology, v.4, n.1, p.96-114, 2013.

Asbahani AE, Miladi K, Badri W, Sala M, Addi EHA, Casabianca $\mathrm{H}$ et al. Essential oils: From extraction to encapsulation. International Journal of Pharmaceutics, v.483, n.1-2, p.220-243, 2015. https://doi.org/10.1016/j.ijpharm.2014.12.069

Assey GE, Mgohamwende R, Malasi WS. A review of the impact of pesticides pollution on environment including effects, benefits and control. Journal of Pollution Effects \& Control, v.9, n.4, 282, 2021. https:// doi: 10.35248/23754397.21.9.282

Barlaam A, Traversa D, Papini R, Giangaspero A. Habronematidosis in equids: Current status, advances, future challenges. Frontiers in Veterinary Science, v.7, 582, 2020. https:// doi: 10.3389/fvets.2020.00358

Bartlow AW, Manore C, Xu C, Kaufeld KA, Valle SD, Ziemann A, Fairchild G, Fair JM. Forecasting zoonotic infectious disease response to climate change: Mosquito vectors and a changing environment. Veterinary Sciences, v.6, n. $2,40,2019$. https://doi.org/10.3390/vetsci6020040

Bellich B, D’Agostino I, Semeraro S, Gamini A, Cesàro A. "The Good, the Bad and the Ugly" of chitosans. Marine drugs, v.14, n.5:99, 2016. https://doi.org/10.3390/md14050099

Bhumkar DR, Pokharkar VB. Studies on effect of $\mathrm{pH}$ on cross-linking of chitosan with sodium tripolyphosphate: A technical note. AAPS PharmSciTech, v.7, n.2, p. E138E143, 2006. https://doi.org/10.1208/pt070250

Bradshaw CJA, Leroy B, Bellard C, Roiz D, Albert C, Fournier $\mathrm{A}$ et al. Massive yet grossly underestimated global costs of invasive insects. Nature Communications, v.7, 12986, 2016. https://doi.org/10.1038/ncomms12986

Calo JR, Crandall PG, O’Bryan CA, Ricke S. Essentials oils as antimicrobials in food systems - A review. Food Control, v.54, p.111-119, 2015. https://doi.org/10.1016/j.foodcont.2014.12.040

Campos EVR, Oliveira JL, Fraceto LF, Sing B. Polysaccharides as safer release systems for agrochemicals. Agronomy for Sustainable Development, v.35, p.47-66, 2015. https://doi.org/10.1007/s13593-014-0263-0

Campos EVR, Proença PLF, Oliveira JL, Pereira AES, Ribeiro LNM, Fernandes FO et al. Carvacrol and linalool coloaded in $\beta$-cyclodextrin-grafted chitosan nanoparticles as sustainable biopesticide aiming pest control. Scientific Reports, v.8, 623, 2018. https://doi.org/10.1038/s41598-01826043-x

Canelles Q, Aquilué N, James PMA, Lawler J, Brotons L. Global review on interactions between insect pests and other forest disturbances. Landscape Ecology, v.36, n.4, p.945-972, 2021. https://doi.org/10.1007/s10980-02101209-7 
Cooper J, Dobson H. The benefits of pesticides to mankind and the environment. Crop Protection, v.26, n.0, p.13371348, 2007. https://doi.org/10.1016/j.cropro.2007.03.022

Dahmana H, Mediannikov O. Mosquito-borne diseases emergence/resurgence and how to effectively control it biologically. Pathogens, v.9, n.4, 310, 2020. https://doi.org/10.3390/pathogens 9040310

Dmour I, Taha MO. Novel nanoparticles based on chitosandicarboxylate conjugates via tandem ionotropic/covalent crosslinking with tripolyphosphate and subsequent evaluation as drug delivery vehicles. International Journal of Pharmaceutics, v.529, n.1-2, p.15-31, 2017. https://doi.org/10.1016/j.ijpharm.2017.06.061

Eddleston M. Poisoning by pesticides. Medicine, v.48, n.3, p.214-217, 2020. https://doi.org/10.1016/j.mpmed.2019.12.019

Elsoud MMA, El Kady EM. Current trends in fungal biosynthesis of chitin and chitosan. Bulletin of the National Research Centre, v.43, n.59, 2019. https://doi.org/10.1186/s42269-019-0105-y

Engel MS. Insect evolution. Current Biology, v.25, n.10, p.R868-R872, 2015. https://doi.org/10.1016/j.cub.2015.07.059

Evans T. Predicting ecological impacts of invasive termites. Current Opinion in Insect Science, v.46, p.88-94, 2021. https://doi.org/10.1016/j.cois.2021.03.003

FAO; WHO. Guidelines for the registration of microbial, botanical and semiochemical pest control agents for plant protection and public health uses: International code of conduct on pesticide management. 76p. 2017. Disponível em: https://www.who.int/whopes/resour-

ces/WHO_HTM_NTD_WHOPES_2017.05/en/. Acesso em: 07 ago 2020 .

Ferreira TP, Haddi K, Corrêa RFT, Zapata VLB, Piau TB, Souza LFN et al. Prolonged mosquitocidal activity of Siparuna guianensis essential oil encapsulated in chitosan nanoparticles. PLoS Neglected Tropical Diseases, v.13, n.8, e0007624, 2019. https://doi.org/10.1371/journal.pntd.0007624

Ferreira TP, Oliveira EE, Tschoeke PH, Pinheiro RG, Maia AMS, Aguiar RWS. Potential use of Negramina (Siparuna guianensis Aubl.) essential oil to control wax moths and its selectivity in relation to honey bees. Industrial Crops e Products, v.109, p.151-157, 2017. https://doi.org/10.1016/j.indcrop.2017.08.023

Ghormade V, Deshpande MV, Paknikar KM. Perspectives for nano-biotechnology enabled protection and nutrition of plants. Biotechnology Advances, v. 29, n. 6, p. 792-803, 2011. https://doi.org/10.1016/j.biotechadv.2011.06.007

Glare T, Caradus J, Gelernter W, Jackson T, Keyhani N, Köhl J et al. Have biopesticides come of age? Trends in Biotechnology, v. 30, n. 5, p.250-258, 2012. https://doi.org/10.1016/j.tibtech.2012.01.003

González JOW, Gutiérrez MM, Ferrero AA, Band BF. Essential oils nanoformulations for stored-product pest control Characterization and biological properties. Chemosphere, v.100, p.130-138, 2014. https://doi.org/10.1016/j.chemosphere.2013.11.056
González JOW, Jesser EN, Yeguerman CA, Ferrero AA, Band BF. Polymer nanoparticles containing essential oils: new options for mosquito control. Environmental Science Pollution Research, v.24, n.20, p.17006-17015, 2017. https://doi.org/10.1007/s11356-017-9327-4

González JOW, Stefanazzi N, Murray AP, Ferrero AA, Band $B F$. Novel nanoinsecticides based on essential oils to control the german cockroach. Journal of Pest Science, v.88, p.393-404, 2015. https://doi.org/10.1007/s10340-0140607-1

González JW, Yeguerman C, Marcovecchio D, Delrieux C, Ferrero A, Band BF. Evaluation of sublethal effects of polymer-based essencial oils nanoformulation on the german cockroach. Ecotoxicology and Environmental Safety, v.130, p.11-18, 2016. https://doi.org/10.1016/j.ecoenv.2016.03.045

Govindarajan M, Benelli G. Artemisia absinthium-borne compounds as novel larvicides: effectiveness against six mosquito vectors and acute toxicity on non-target aquatic organisms. Parasitology Research, v.115, n.12, p.46494661, 2016. https://doi.org/10.1007/s00436-016-5257-1

Hamed I, Özogul F, Regenstein JM. Industrial applications of crustacean by-products (chitin, chitosan, and chitooligosaccharides): A review. Trends in Food Science e Technology, v.48, p.40-50, 2016

https://doi.org/10.1016/j.tifs.2015.11.007

Hejjaji EMA, Smith AM, Morris GA. Evaluation of the mucoadhesive properties of chitosan nanoparticles prepared using different chitosan to tripolyphosphate (CS:TPP) ratios. International Journal of Biological Macromolecules, v.120B, p.1610-1617, 2018. https://doi.org/10.1016/j.ijbiomac.2018.09.185

Islam N, Dmour I, Taha MO. Degradability of chitosan micro/nanoparticles for pulmonary drug delivery. Heliyon, v.5, n.5, e01684, 2019. https://doi.org/10.1016/j.heliyon.2019.e 01684

Isman MB. A renaissance for botanical insecticides? Pest Management Science, v.71, n.12, p.1587-1590, 2015. https://doi.org/10.1002/ps.4088

Isman MB, Grieneisen ML. Botanical insecticide research: Many publications, limited useful data. Trends in Plant Science, v.19, n.3, p.14-145, 2014. https://doi.org/10.1016/j.tplants.2013.11.005

Isman, MB, Miresmailli S, Machial C. Commercial opportunities for pesticides based on plant essential oils in agriculture, industy and consumer products. Phytochemistry Reviews, v.10, p.197-204, 2011. https://doi.org/10.1007/s11101-010-9170-4

Kamutz M, Jezierski T. Ecological, behavioural and economic effects of insects on grazing farm animals - a review. Animal Science Papers and Reports, v.32, n.2, p.107-119, 2014.

Lammari N, Louaer O, Meniai AH, Fessi H. Plant oils: From chemical composition to encapsulated form use. International Journal of Pharmaceutics, v.601, 120538, 2021. https://doi.org/10.1016/j.ijpharm.2021.120538

Leftwich PT, Bolton M, Chapman T. Evolutionary biology and genetic techniques for insect control. Evolutionary 
Applications, v.9, n.1, p.212-230, 2016.

https://doi.org/10.1111/eva.12280

Liao M, Xiao J-J, Zhou L-J, Yao X, Tang F, Hua R-M et al. Chemical composition, insecticidal and biochemical effects of Melaleuca alternifolia essential oil on the Helicoverpa armigera. Journal of Applied Entomology, v.141, n.9, p.721-728, 2017. https://doi.org/10.1111/jen.12397

Majeed H, Bian Y-Y, Ali B, Jamil J, Majeed U, Khan QF et al. Essential oil encapsulations: uses, procedures, and trend. RSC Advances, v.5, n.72, p.58449-58463, 2015. https://doi.org/10.1039/C5RA06556A

Marque NN, Alves KS, Vidal RRL, Maia AMS, Madruga LYC, Curti PS et al. Chemical modification of polysaccharides and applications in strategic areas. In: Emerging Research in Science and Engineering Based on Advanced Experimental and Computational Strategies. La Porta, F. A.; Taft, C. A. editors. Springer, 530p. 2020.

Melo, BA, Oliveira SR, Leite DT, Barreto CF, Silva HS. Inseticidas botânicos no controle de pragas de produtos armazenados. Revista Verde, v.6, n.4, p.1-10, 2011.

Mendes LA, Martins GF, Valbon WR, Souza TS, Menini L, Ferreira A et al. Larvicidal effect of essential oils from Brazilian cultivars of guava on Aedes aegypti L. Industrial Crops e Products, v.108, p.684-689, 2017. https://doi.org/10.1016/j.indcrop.2017.07.034

Miresmailli S, Isman MB. Botanical insecticides inspired by plant-herbivore chemical interactions. Trends in Plant Science, v.19, n.1, p.29-35, 2014.

https://doi.org/10.1016/j.tplants.2013.10.002

Nazarzadeh E, Anthonypillai T, Sajjadi S. On the growth mechanisms of nanoemulsions. Journal of Colloid and Interface Science, v.397, p.154-162, 2013. https://doi.org/10.1016/j.jcis.2012.12.018

Oliveira CM, Auad AM, Mendes SM, Frizzas MR. Crop losses and the economic impact of insect pests on Brazilian agriculture. Crop Protection, v.56, p.50-54, 2014. https://doi.org/10.1016/j.cropro.2013.10.022

Ootani MA, Aguiar RW, Ramos ACC, Brito DR, Silva JB et al. Use of essential oils in agriculture. Journal of Biotechnology and Biodiversity, v.4, n.2, p.162-174, 2013.

Paula HCB, Sombra FM, Abreu FOMS, Paula RCM. Lippia sidoides essential oil encapsulation by angico gum/chitosan nanoparticles. Journal of the Brazilian Chemical Society, v.21, n.12, p.2359-2366, 2010. https://doi.org/10.1590/S0103-50532010001200025

Paulraj MG, Ignacimuthu S, Gandhi MR, Shajahan A, Ganesan P, Packiam SM, Al-Dhabi NA. Comparative studies of tripolyphosphate and glutaraldehyde cross-linked chitosanbotanical pesticide nanoparticles and their agricultural applications. International Journal of Biological Macromolecules, v.104, p.1813-1819, 2017.

https://doi.org/10.1016/j.ijbiomac.2017.06.043

Pavela R. Essential oils for the development of eco-friendly mosquito larvicides: A review. Industrial Crops and Products, v.76, p.174-187, 2015. https://doi.org/10.1016/j.indcrop.2015.06.050

Pavela R. Encapsulation - a convenient way to extend the persistence of the effect of eco-friendly mosquito larvicides. Current Organic Chemistry, v.20, n.25, p.26742680, 2016. 10.2174/1385272820666151026231851

Queiroz RM, Takiya CM, Guimarães LPTP, Rocha GG, Alviano DS, Blank AF et al. Apoptosis-inducing effects of Melissa officinalis L. essential oil in glioblastoma multiforme cells. Cancer Investigation, v.32 n.6, p.226-235, 2014. https://doi.org/10.3109/07357907.2014.905587

Rader R, Bartomeus I, Garibaldi LA, Garratt MPD. Howlett BG, Winfree $\mathrm{R}$ et al. Non-bee insects are important contributors to global crop pollination. Proceedings of the National Academy of Sciences, v.113, n.1, p.146-151, 2016. https://doi.org/10.1073/pnas.1517092112

Radulescu M, Jianu C, Lukinich-Gruia AT, Mioc M, Mioc A, Soica $\mathrm{C}$ et al. Chemical composition, in vitro and in silico antioxidant potential of Melissa officinalis subsp. officinalis essential oil. Antioxidants, v.10, n.7, 1081, 2021. https://doi.org/10.3390/antiox10071081

Rajkumar V, Gunasekaran C, Dharmaraj J, Panneerselvam P, Paul CA, Kanithachristy I. Structural characterization of chitosan nanoparticle loaded with Piper nigrum essential oil for biological efficacy against the stored grain pest control. Pesticide Biochemisty and Physiology, v.166, 104566, 2020. https://doi.org/10.1016/j.pestbp.2020.104566

Rajkumar V, Gunasekaran C, Paul CA, Dharmaraj J. Development of encapsulated peppermint essential oil in chitosan nanoparticles: characterization and biological efficacy against stored-grain pest control. Pesticide Biochemisty and Physiology, v.170, 104679, 2020 b. https://doi.org/10.1016/j.pestbp.2020.104679

Rattan RS. Mechanism of action of insecticidal secondary metabolites of plant origin. Crop Protection, v.29, n.9, p.913-920, 2010. https://doi.org/10.1016/j.cropro.2010.05.008

Raut JS, Karuppayil SM. A status on the medicinal properties of essential oils. Industrial Crops and Products, v.62, p.250-264, 2014. https://doi.org/10.1016/j.indcrop.2014.05.055

Regnault-Roger C, Vincent C, Arnason JT. Essential oils in insect control: Low-risk products in a high-stakes world. Annual Review of Entomology, v.57, p.405-424, 2012. https://doi.org/10.1146/annurev-ento-120710-100554

Russo L, Keyzer CW, Harmon-Threatt AN, LeCroy KA, Maclvor JS. The managed-to-invasive species continuum in social and solitary bees and impacts on native bee conservation. Current Opinion in Insect Science, v.46, p.4349, 2021. https://doi.org/10.1016/j.cois.2021.01.001

Santos TLB, Turchen LM, Dall'Oglio EL, Butnariu AR, Pereira MJB. Phytochemical of Piper essential oil and acute toxicity against Helicoverpa armigera (Lepidoptera: Noctuidae). Revista Brasileira de Ciências Agrárias, v.12, n.4, p.484-489, 2017. https://doi.org/10.5039/agraria.v12i4a5482

Sarmento-Brum RBC, Castro HG, Gama FR, Cardon CH, Santos BR. Phytotoxicity of essential oils in watermelon, bean and rice plans. Journal of Biotechnology and Biodiversity, v.5, n.2, p.101-109, 2014.

Sharmeen JB, Mahomoodally FM, Zengin G, Maggi, F. Essential oils as natural sources of fragrance compounds for 
cosmetics and cosmeceuticals. Molecules, v.26, n.3, 666, 2021. https://doi.org/10.3390/molecules 26030666

Sharma S, Barkauskaite S, Jaiswal AK, Jaiswal S. Essential oils as additives in active food packaging. Food Chemistry, v.343, 128403, 2021. https://doi.org/10.1016/j.foodchem. 2020.128403

Sparks TC, Wessels FJ, Lorsbach BA, Nugent BM, Watson GB. The new age of insecticide discovery-the crop protection industry and the impact of natural products. Pesticide Biochemistry and Physiology, v.161, p.12-22, 2019. https://doi.org/10.1016/j.pestbp.2019.09.002

Tudi M, Ruan HD, Wang L, Lyu J, Sadler R, Connell D etal. Agriculture development, pesticide application and its impact on the environment. International Journal of Environmental Research and Public Health v.18, n.3, 1112, 2021. https://doi.org/10.3390/ijerph18031112

Turek C, Stintzing FC. Stability of essential oils: A review. Comprehensive Reviews in Food Science and Food Safety, v.12, n.1, p.40-53, 2013. https://doi.org/10.1111/15414337.12006

Upadhyay N, Singh VK, Dwivedy AK, Das S, Chaudhari AK, Dubey NK. Assessment of Melissa officinalis L. Essential oil as an eco-friendly approach against biodeterioraton of wheat flour caused by Tribolium castaneum Herbst. Environmental Science and Pollution Research, v.26, p.14036-14049, 2019. https://doi.org/10.1007/s11356-01904688-z

Vllasaliu D, Exposito-Harris R, Heras A, Casettari L, Garnett $\mathrm{M}$, Illum L et al. Tight junction modulation by chitosan nanoparticles: comparison with chitosan solution. International Journal of Pharmaceutics, v.400, n.1-2, p.183-193, 2010. https://doi.org/10.1016/j.ijpharm.2010.08.020

Weidner C, Rousseau M, Plauth A, Wowro SJ, Fischer C, Abdel-Aziz H, Sauer S. Melissa officinalis extract induces apoptosis and inhibits proliferation in colon cancer cells through formation of reactive oxygen species. Phytomedicine, v.22, n.2, p.262-270, 2015.

https://doi.org/10.1016/j.phymed.2014.12.008

WHO. Vector-borne diseases. Disponível em: https://www.who.int/news-room/fact-sheets/detail/vectorborne-diseases\#. Acesso em: 10 de ago. 2020.

Wong STS, Kamari A, Jaafar AM, Hussein MZ, Othman H, Abdullah $\mathrm{H}$ et al. Longer mosquito control using a sodium alginate-chitosan nanocarrier for cinnamaldehyde in larvicide formulations. Environmental Chemistry Letters, v.18, p.1345-1351, 2020. https://doi.org/10.1007/s10311-02000993-Z

Yang F-L, Li X-G, Zhu F, Lei C-L. Structural characterization of nanoparticle loaded with garlic essential oil and their insecticidal activity against Tribolium castaneum (Herbst) (Coleoptera: Tenebrionidae). Journal of Agricultural and Food Chemisty, v.57, n.21, p.10156-10162, 2009. https://doi.org/10.1021/jf9023118

You M, Xu D, Cai H, Vasseeur L. Practical importance for conservation of insect diversity in China. Biodiversity and Conservation, v.14, p.723-737, 2005.

https://doi.org/10.1007/s10531-004-3922-7

Ziaee M, Moharramipour S, Mohsenifar A. MA-chitosan nanogel loaded with Cuminum cyminum essential oil for efficient management of two stored product beetle pests. Journal of Pest Science, v.87, p.691-699, 2014a. https://doi.org/10.1007/s10340-014-0590-6

Ziaee M, Moharramipour S, Mohsenifar A. Toxicity of Carum copticum essential oil-loaded nanogel against Sitophilus granarius and Tribolium confusum. Journal of Applied Entomology, v.138, n.10, p.763-771, 2014b. https://doi.org/10.1111/jen.12133 